\title{
Article/Artigo
}

\section{Quantification of HIV-1 viral RNA in the blood in needles used for venous puncture in $\mathrm{HIV}$-infected individuals}

\author{
Quantificação do HIV-1 RNA viral no sangue de agulhas usadas para punção venosa em \\ indivíduos infectados pelo HIV
}

Iris Ricardo Rossin ${ }^{1}$, Alcyone Artioli Machado ${ }^{1}$, Érica Maria Junqueira ${ }^{2}$ and Roberto Martinez ${ }^{1}$

\begin{abstract}
Introduction: Occupational HIV infection among healthcare workers is an important issue in exposures involving blood and body fluids. There are few data in the literature regarding the potential and the duration of infectivity of HIV type 1 (HIV-1) in contaminated material under adverse conditions. Methods: We quantified HIV-1 viral RNA in $25 \times 8 \mathrm{~mm}$ calibre hollow-bore needles, after punctures, in $25 \mathrm{HIV}$-1-infected patients selected during the sample collection. All of the patients selected were between the ages of 18 and 55. Five samples were collected from 16 patients: one sample for the immediate quantification of HIV-1 RNA in the plasma and blood samples from the interior of 4 needles to be analyzed at $0 \mathrm{~h}, 6 \mathrm{~h}, 24 \mathrm{~h}$, and $72 \mathrm{~h}$ after collection. In nine patients, another test was carried out in the blood from one additional needle, in which HIV-1 RNA was assessed $168 \mathrm{~h}$ after blood collection. The method used to assess HIV-1 RNA was nucleic acid sequence-based amplification. Results: Up to 7 days after collection, HIV-1 RNA was detected in all of the needles. The viral RNA remained stable up to $168 \mathrm{~h}$, and there were no statistically significant differences among the needle samples. Conclusions: Although the infectivity of the viral material in the needles is unknown, the data indicate the need to re-evaluate the practices in cases of occupational accidents in which the source is not identified.
\end{abstract}

Keywords: Occupational exposure. Health personnel. Needlestick injuries. HIV-1 viral load. Polymerase chain reaction.

\section{RESUMO}

Introdução: A infecção ocupacional pelo HIV entre os trabalhadores de saúde é uma importante questão em exposições envolvendo sangue e fluidos corporais. Os dados na literatura são escassos quanto ao potencial infectivo do HIV-1 em material contaminado e o intervalo de tempo em que a infectividade é mantida em condições adversas. Métodos: Realizamos a quantificação de RNA viral do HIV-1 em agulhas ocas com calibre $25 \mathrm{X} 8 \mathrm{~mm}$, após punções, em 25 pacientes infectados pelo HIV-1 selecionados durante coleta de sangue para exames. Todos os pacientes selecionados tinham idade variando entre 18 e 55 anos. De 16 pacientes foram coletadas 5 amostras: 1 amostra de sangue para quantificação imediata do RNA viral do HIV-1 no plasma e 4 agulhas para a análise ás 0 h, 6 h, 24 h e $72 \mathrm{~h}$ após a coleta. Em nove pacientes, um outro teste foi realizado no sangue de uma agulha adicional, na qual foi avaliada a presença de RNA viral do HIV-1 após $168 \mathrm{~h}$ após a coleta do sangue. O método usado para avaliar o RNA do HIV-1 foi a amplificação baseada na sequência de ácidos nucléicos. Resultados: O RNA do HIV-1 foi detectado em todas as agulhas até o sétimo dia após a coleta. O RNA viral manteve-se estável até $168 \mathrm{~h}$ após a punção, sem diferença estatisticamente significante entre as agulhas coletadas. Conclusões: Embora a infectividade do material viral nas agulhas seja desconhecido, os dados apontam necessidade de reavaliação das condutas em casos de acidente com fonte desconhecida.

Palavras-chaves: Exposição ocupacional. Trabalhadores da saúde. Acidentes perfurocortantes. Carga viral do HIV-1. Reação de polimerase em cadeia.

1. Departamento de Clínica Médica, Faculdade de Medicina de Ribeirão Preto, Universidade de São Paulo, Ribeirão Preto, SP. 2. Hospital das Clínicas da Faculdade de Medicina de Ribeirão Preto, Universidade de São Paulo, Ribeirão Preto, SP.

Address to: Profa. Alcyone Artioli Machado. Depto. Clinica Médica/FMRP. Av. Bandeirantes 3900, Campus Universitário, 14048-900 Ribeirão Preto, SP, Brasil.

Phone: 5516 3633-0436; Fax: $55163633-6695$

e-mail: aamachad@fmrp.usp.br

Received in 05/08/2010

Accepted in 08/08/2011

\section{INTRODUCTION}

It is estimated that there are currently 33 million people infected with HIV type 1 (HIV-1) worldwide ${ }^{1}$. Providing medical care for these individuals represents a risk to healthcare workers (HCWs), as they can also be infected through direct contact with blood and other body fluids in mucosae or skin substitutes, as well as through sharps injuries ${ }^{2-3}$.

Cases of occupational contamination with HIV1 have been reported; the first was in December of $1984^{4}$. From the beginning of the AIDS epidemic in 1981 up to 2002, there have been 106 confirmed cases and 238 probable cases of $\mathrm{HCWs}$ contaminated with HIV through occupational accidents. According to the Centers for Disease Control (CDC), 57 (53.7\%) of the 106 confirmed cases occurred in the United States, which also accounted for 140 (58.8\%) of the probable cases ${ }^{1}$.

The infective potential of HIV-1 in experimental models of occupational exposure is fairly well known ${ }^{5-6}$. However, many questions remain concerning transmission outside controlled laboratory conditions, as in occupational exposure. There seem to be many determining factors: the time elapsed between the contamination and the exposure, the quantity of inoculate, the type of fluid, the depth and extent of the lesion, the body site affected, and the environmental conditions ${ }^{7-9}$.

Epidemiological data show a strong correlation between the HIV-1 viral load of the index case and the risk of infectivity ${ }^{10}$.

Among the various types of occupational exposure to blood and body fluids, needlestick with a hollowbore needle is the most frequently reported among nursing staff, accounting for more than $90 \%$ of the cases ${ }^{1,11-14}$. The majority of the incidents of occupational HIV exposure among HCWs have involved needles ${ }^{8,15-18}$.

Due to this observation, detecting HIV-1 viral RNA in hollow-bore needles at different periods after the contamination could provide new data on the biological risks for HCWs. 


\section{METHODS}

We randomly selected $25 \mathrm{HIV}$-1-infected individuals from among those under treatment at the Hospital das Clínicas da Faculdade de Medicina de Ribeirão Preto da Universidade de São Paulo (HCFMRP, Hospital das Clínicas of the University of São Paulo Ribeirão Preto School of Medicine), located in the City of Ribeirão Preto, State of São Paulo, Brazil. Of those 25 patients, 13 were hospitalized due to AIDS-related incidents, and 12 were being followed up as outpatients. At the time of inclusion (collection), 16 patients had previously presented AIDS-defining illnesses. Staging of the HIV-1 infection was carried out according to the CDC classification system ${ }^{19}$. We consecutively collected blood samples, one by one, directly from the veins of the patients using sterile, previously unused needles $(25 \times 8 \mathrm{~mm}$; Becton Dickinson, Franklin Lakes, NJ, USA). Five blood samples were collected from each of the 16 individuals testing positive for HIV-1 viral RNA: one sample into a tube containing EDTA for the quantification of the viral load in plasma and four additional samples, which remained in the needles for analysis at $0 \mathrm{~h}, 6 \mathrm{~h}, 24 \mathrm{~h}$, and $72 \mathrm{~h}$ after collection. In nine individuals, one additional sample was collected for analysis after seven days (at 168h). The sample in the tube and the needles used in the collection were sent to the HCFMRP Molecular Biology Laboratory. The needles were stored in individual metal boxes, previously sterilized in ethylene oxide, and stored in a temperature-controlled environment (constant temperature, $25^{\circ} \mathrm{C}$ ) until the time scheduled for the tests to quantify the HIV-1 viral RNA.

To ascertain the quantity of blood contained in the needle lumen, we first weighed an unused sterile needle using a scale (PL1200; Mettler-Toledo, Toledo, OH, USA). We subsequently weighed the needles containing the blood samples and subtracted the weight of the unused needle, which gave us the weight of the blood in the lumen. Based on this value, we calculated the quantity of buffer solution and calibrators to be used in the tests. The blood was flushed from the needle lumen with a flow of chemical buffer solution. Viral loads were expressed in log-transformed values. Quantification of the viral load in all the samples was carried out using the nucleic acid sequence-based amplification (NASBA) method (NucliSens QT System; bioMérieux, Marcy l'Étoile, France).

With the aim of establishing a control group, we invited 4 HIV1 -seronegative individuals to participate by undergoing in the same procedures as those performed in the study group.

\section{Ethical considerations}

The procedures were explained in advance to the participants; all of whom then gave written informed consent. The study design was approved by the HCFMRP Research Ethics Committee (Process n 6294/2001).

\section{RESULTS}

The 25 patients presented different stages of HIV infection (CDC 2008) - stage III (AIDS) in 23 cases and stage II in 2 cases. There were 9 patients who had never presented an AIDS-defining infection. Among those nine patients, CD4+ lymphocyte counts were $<200$ cells $/ \mu \mathrm{L}$ in 5 patients and $\geq 200$ cells $/ \mu \mathrm{L}$ in 4 patients -2 of whom were asymptomatic. The CD4+ counts ranged from 3 to 1248 cells $/ \mu \mathrm{L}$ (mean, 216 cells $/ \mu \mathrm{L}$; median, 21.5 cells $/ \mu \mathrm{L}$ ). In the sample as a whole, CD4+ counts were $<200$ cells $/ \mu \mathrm{L}$ in 15 patients,
$>500$ cells $/ \mu \mathrm{L}$ in 3 , and $200-500$ cells $/ \mu \mathrm{L}$ in the remaining patients. In 5 patients, there was no detectable viral load, but it ranged from $1.95 \log _{10}$ copies/mL to $5.88 \log _{10}$ copies $/ \mathrm{mL}$ in the remaining 20 patients. A value higher than $5.00 \log _{10}$ copies $/ \mathrm{mL}$ (>100,000 copies $/ \mathrm{mL}$ ) was found in 6 patients. In the remaining patients, the viral load ranged from $1.95 \log _{10}$ copies $/ \mathrm{mL}$ to $4.96 \log _{10}$ copies $/ \mathrm{mL}$.

Of the 25 patients studied, 10 were not on antiretroviral therapy at the time of their enrolment in the study, 3 were using four antiretroviral drugs, and 12 were using three antiretroviral drugs. Lamivudine and efavirenz were the antiretroviral drugs most commonly used.

Table 1 shows the viral loads for the material contained in the 109 needles used in the collection of blood from, as well as for the plasma of, the 25 HIV-1-infected patients. The HIV-1 viral loads were expressed in log-transformed values of the number of copies $/ \mathrm{mL}$.

The viral load determined for the material contained in the lumens of the 109 needles used in punctures of the 25 patients studied ranged from undetectable to $8.24 \log _{10}$ copies $/ \mathrm{mL}$ (mean, $4.49 \log _{10}$ copies/mL; median, $5.05 \log _{10}$ copies $/ \mathrm{mL}$ ). The viral load remained undetectable in the material obtained from the needles used in patients presenting an undetectable viral load in plasma at the study outset. None of the individuals in the control group presented a detectable viral load.

TABLE 1 - Log-transformed values for HIV-1 viral loads found in the material contained in the needles used for the collection of blood, at collection (baseline) and at different post-collection time points, as well as in the plasma of the 25 HIV-1-infected patients.

\begin{tabular}{|c|c|c|c|c|c|c|}
\hline \multirow[b]{3}{*}{ Patient } & \multicolumn{6}{|c|}{ Viral load ${ }^{a}, \log _{10}$ copies $/ \mathrm{mL}$} \\
\hline & Needle 1 & Needle 2 & Needle 3 & Needle 4 & Needle 5 & Plasma \\
\hline & Baseline & $6 \mathrm{~h}$ & $24 \mathrm{~h}$ & $72 \mathrm{~h}$ & $168 h$ & Baseline \\
\hline 1 & 5.50 & 7.38 & 7.53 & 6.77 & NP & 3.00 \\
\hline 2 & 7.66 & 7.81 & 7.38 & 7.20 & NP & 5.88 \\
\hline 3 & 7.47 & 7.06 & 7.53 & 8.13 & NP & 5.70 \\
\hline 4 & 6.31 & 6.50 & 7.28 & 7.88 & NP & 4.25 \\
\hline 5 & 6.53 & 7.56 & 8.24 & 8.03 & NP & 2.90 \\
\hline 6 & 6.97 & 7.50 & 7.30 & 7.06 & NP & 4.96 \\
\hline 7 & 7.47 & 7.95 & 7.54 & 7.56 & NP & 5.85 \\
\hline 8 & 7.90 & 7.17 & 6.97 & 7.69 & NP & 3.54 \\
\hline 9 & 7.69 & 7.59 & 7.92 & 7.57 & NP & 5.62 \\
\hline 10 & 7.19 & 7.26 & 6.41 & 7.65 & NP & 4.47 \\
\hline 11 & 6.05 & 6.57 & 7.50 & 6.56 & NP & 3.74 \\
\hline 12 & undetec & undetec & undetec & undetec & NP & undetec \\
\hline 13 & undetec & undetec & undetec & undetec & NP & undetec \\
\hline 14 & undetec & undetec & undetec & undetec & NP & undetec \\
\hline 15 & undetec & undetec & undetec & undetec & NP & undetec \\
\hline 16 & undetec & undetec & undetec & undetec & NP & undetec \\
\hline 17 & 6.62 & 6.31 & 6.69 & 7.19 & 6.87 & 4.41 \\
\hline 18 & 6.20 & 6.10 & 6.86 & 6.38 & 6.74 & 4.30 \\
\hline 19 & 7.03 & 7.01 & 6.08 & 6.00 & 7.38 & 5.14 \\
\hline 20 & 6.14 & 6.71 & 5.18 & 6.56 & 6.57 & 3.83 \\
\hline 21 & 6.20 & 6.13 & 5.05 & 5.50 & 7.38 & 1.95 \\
\hline 22 & 5.82 & 6.13 & 6.30 & 6.25 & 5.01 & 4.35 \\
\hline 23 & 6.90 & 7.09 & 6.81 & 5.17 & 4.28 & 4.85 \\
\hline 24 & 6.97 & 6.77 & 7.04 & 6.72 & 6.95 & 5.04 \\
\hline 25 & 5.51 & 6.13 & 5.17 & 4.28 & 5.19 & 3.56 \\
\hline
\end{tabular}

NP: not performed; undetec: undetectable; $\boldsymbol{a}$ : overall viral load in the needles: mean, $4.49 \log _{10}$ copies $/ \mathrm{mL}$; median, $5.05 \log _{10}$ copies $/ \mathrm{mL}$. 
The data obtained in the quantification of HIV-1 viral RNA were analyzed through multiple comparisons using the Tukey-Kramer test and the analysis of variance (ANOVA) for repeated measures. The HIV-1 viral RNA values did not differ significantly $(p>0.05)$ at any of the time points at which multiple comparisons were carried out ( $0 \mathrm{~h}, 6 \mathrm{~h}, 24 \mathrm{~h}, 72 \mathrm{~h}$, and $168 \mathrm{~h})$, suggesting that the viral material was preserved in the blood contained within the needle lumens. The presence of HIV-1 viral load remained stable in the samples tested at $72 \mathrm{~h}$ after collection. In the 9 cases in which HIV-1 viral RNA was quantified at $168 \mathrm{~h}$ after puncture, the samples presented insignificant variations between the time of collection and the time of the test. There was no statistically significant difference between the time of collection and the designated time points analyzed nor was there any statistically significant difference between any two given time points.

\section{DISCUSSION}

The study of hollow-bore needles is particularly important due to the frequency with which they are involved in accidents and to the strong evidence shown in epidemiological studies of a higher rate of contamination related to accidents caused by this type of equipment ${ }^{19-21}$.

Studies undertaken outside laboratory conditions have shown that it is possible to identify HIV-1 in the most varied sources and under the most adverse condition $\mathrm{s}^{22}$ by using quantitative polymerase chain reaction (PCR) and detecting viral RNA on surfaces contaminated with blood at up to seven days after contamination. Using nested PCR, Shah et al. ${ }^{12}$, detected viral particles of HIV-1 on a variety of objects visibly contaminated with blood, such as bits of cotton, spoons, lavatories, syringes, and needles collected at random from locales frequented by users of illicit injectable drugs.

In the present study, we used the NASBA method and detected HIV-1 RNA at up to seven days after collection in 89 needles used in the collection of blood samples in patients with detectable viral loads. The NASBA method was chosen because it has certain advantages: It can be used with small volume samples $(100-2,000 \mu \mathrm{L})$, it possesses a broad dynamic range that permits 10 to $10^{9}$ copies to be obtained in under an hour, its detection limit is 80 copies/mL of RNA, and the reaction does not require temperature cycles. In addition, the RNA product extracted is relatively pure and free of substances that might inhibit amplification, which is why the NASBA method is commonly used for the determination of viral load in many types of organic tissue and fluids in which there may be interference from other substances ${ }^{23}$.

The finding of an undetectable viral load, at different postpuncture time points, in the 20 needles used in the 5 patients presenting an undetectable viral load at baseline (collection) indicates the accuracy of the method used.

The data obtained from this experimental trial, which was conducted under controlled conditions that simulate occurrences in the environment, are important for the establishment of preventive behaviours. Like Abdala et al. ${ }^{24}$, we understand that in objects containing lumens, particular conditions that are different from those in the external environment can arise within their lumens, thus creating a propitious environment for the survival of the virus for an undetermined period of time.

The persistence of a viral load in material preserved by chance within needles is, at the very least, worrisome, suggesting that the virus has the potential of replication and could be transmitted, even after a long period of exposure to conditions that are theoretically adverse.

The viral dynamic and viability of HIV under well-controlled laboratory conditions have been well established ${ }^{25-26}$. Experimental data obtained by the CDC show that when fluids contaminated with HIV are dehydrated, there is a progressive reduction in the recuperation of the virus using qualitative PCR, the reduction being quite pronounced in the first hours ${ }^{7}$. Corser ${ }^{27}$ showed the survival rate of HIV to be low when exposed directly to the environment. Moudgil and Daar ${ }^{22}$ studied material outside laboratory conditions and found that it was possible to recover viable viral material from the most unlikely sources, even under adverse conditions. The discordance between the results obtained in the present study and those of other studies might be attributable to differences in the methodologies used.

The data obtained in our study suggest that the viral material was preserved in the internal microenvironment of the hollow-bore needles evaluated.

The analysis of the variation in viral load found in the lumen of the needles, expressed in log-transformed values, which is the parameter of clinical significance in the evaluation of HIV-1 viral load in patients, revealed no statistically significant differences. However, there were certain notable peculiarities, as in the laboratory procedures related to the treatment of HIV-1 infection, variations between viral load quantification time points are of clinical significance, which might not be the case when statistical methods are applied.

The plasma viral load cannot be compared with that of the needles, as the needles contain whole blood.

Viral culture was not undertaken in human lymphocytes or in animal models, representing an intrinsic limitation of the present study and making it impossible to determine whether the viral material in the needles was viable or was composed merely of viral RNA fragments. Abdala et al. ${ }^{24}$, studied the survival rate of HIV in microcultures of blood samples $(2-20 \mu \mathrm{L}$ of material) obtained from needles contaminated with HIV and maintained under environmental conditions. The authors demonstrated that it is possible to isolate the virus at up to four weeks after contamination of the needles. Using nested PCR, Shah et al. ${ }^{12}$, were able to isolate viral particles of HIV-1 on various objects visibly contaminated with blood that were collected from locales frequented by drug users ${ }^{25}$.

The data obtained in the present study, despite the limitations described, draw attention to the need to re-evaluate behaviour in cases of sharps injuries involving blood and body fluids among HCWs in which the source was not identified, as current practices seem to be based on an underestimation of the survival rate of the virus under adverse conditions.

\section{ACKNOWLEDGMENTS}

The authors would like to thank Dr. Cristiane Rapparini for her suggestions that were indispensable for the preparation of this manuscript.

\section{CONFLICT OF INTEREST}

The authors declare that there is no conflict of interest. 


\section{FINANCIAL SUPPORT}

This study is supported by the Foundation for the Support of Instruction, Research and Treatment.

\section{REFERENCES}

1. World Health Organization. The UNAIDS/WHO Global HIV/AIDS Online Database-dynamic report generator of the Epidemiological Fact Sheets on HIV/ AIDS and Sexually Transmitted Infections [Internet]. [updated 2010 June 15; cited 2010 June 15] Available from: http://www.who.int/GlobalAtlas/home. asp/.

2. Gerberding JL. Occupational exposure to HIV in health care settings. N Engl J Med 2003; 348: 826-833.

3. Katz MH, Gerberding JL. Management of occupational and nonoccupational postexposure HIV prophylaxis. Curr HIV/AIDS Rep 2004; 1:159-165.

4. Anonymous. Needlesticks transmission of HTLV-III from a patient infected in Africa. Lancet 1984; 8416-2: 1376-1377.

5. Tjotta E, Hungnes O, Bjorn G. Survival of HIV-1 Activity After Disinfection, Temperature and pH Changes, or Drying. J Med Virol 1991; 35:223-227.

6. Kuruuzum Z, Yapar N, Avkan-Oguz V, Aslan H, Ozbek OA, Cakir N. Risk of infection in health care workers following occupational exposure to a noninfectious or unknown source. Am J Infect Control 2008; 36:27-31.

7. Centers fo Disease Control and Prevention. Centers for Disease Control and Prevention Surveillance of Occupationally Acquired HIV/AIDS in Healthcare Personnel [Internet]. Atlanta: CDC. [cited 2010 June 15]. Available from: http//:www.cdc.gov/.

8. Occupational Safety and Health Administration. Occupational Safety and Health Administration. Record summary of the request for information on occupational exposure to bloodorne pathogens during to percutaneous injury. Washington, (DC): Department of Labor, Occupational Safety and Health Administration. [updated 2010 June 15; cited 2010 June 15] Available from: http://www.osha. gov/.

9. Wicker S, Cinatl J, Berger A, Doerr HW, Gottschalk R, Rabenau HF. Determination of risk of infection with blood-borne pathogens following a needlestick injury in hospital workers. Ann Occup Hyg 2008; 52:615-622.

10. Tarantola A, Abiteboul D. Infection risks following accidental exposure to blood or body fluids in health care workers: a review of pathogens transmitted in published cases. Am J Infect Control 2006; 34:367-375

11. Machado AA, Castro G, Abduch R, Figueiredo JFC, Martinez R. Surveillance of accidental HIV-1 contamination among health care workers in Ribeirão Preto, São Paulo, Brazil. Int Conf AIDS 1998; 12:409.

12. Shah SM, Shapshak P, Rivers JE, Stewart RV, Weatherby NL, Xin KQ, et al. Detection of HIV-1 DNA in needle/syringes, paraphernalia, and washes from shooting galleries in Miami: a preliminary laboratory report. Drug Alcohol Depend 2000; 58:153-157.

13. Gimenez-Marino CG, El-Far F, Wey SB, Medeiros EAS. Cut and puncture accidents involving health care workers exposed to biological materials. Braz J Infect Dis 2001; 5:235-242.

14. Merchant RC, Chee KJ, Liu T, Mayer KH. Incidence of visits for health care worker blood or body fluid exposures and HIV postexposure prophylaxis provision at Rhode Island emergency departments. J Acquir Immune Defic Syndr 2008; 47:358-368.

15. Gold J, Tomkins M, Bates N, Melling P, Resnik S, Sheather J. Management of occupational exposures to blood-borne viruses. N Engl J Med 1995; 332: 444-449.

16. Rapparini C. Occupational HIV infection among health care workers exposed to blood and body fluids in Brazil. Am J Infect Control 2006; 34:237-240.

17. National Institute for Occupational Safety and Health. Niosh Alert Preventing Needlestick Injuries in Health Care Settings. [updated 2010 June 15; cited 2010 June 15]. Available from: http://www.cdc.gov/niosh.

18. Centers for Disease Control and Prevention. Revised Surveillance Case Definitions for HIV Infection Among Adults, Adolescents and and Children Aged $<18$ Months and for HIV Infection and AIDS Among Children Aged
18 Months to <13 Years — United States, 2008. Morbid Mortal Wkly Rep $2008 ; 57: 1-8$

19. Beekman SE. Hospital Bloodborne Pathogens Programs: program characteristics and blood and body fluid exposure rates. Infect Control Hosp Epidemiol $2001 ; 22: 73-82$.

20. Young TN, Arens FJ, Kennedy GE, Laurie JW, Rutherford G. Antiretroviral postexposure prophylaxis (PEP) for occupational HIV exposure. Cochrane Database Syst Rev 2007; 24:28-35.

21. Alamgir H, Cvitkovich Y, Astrakianakis G, Yu S, Yassi A. Needlestick and othe potential blood and body fluid exposures among health care workers in British Columbia, Canada. Am J Infect Control 2008; 36:12-21.

22. Moudgil T, Daar ES. Infectious decay of HIV in health care settings. J Infec Dis $1993 ; 167: 210-212$

23. Morse H, Olsvik O. Nucleic Acid Amplification Technologies, Aplication on Diseases Diagnosis. EUA: Eaton Publishing Bio Tec Books; 1997.

24. Abdala N, Stephens PC, Griffith BP, Heimer R. Survival of HIV-1 in Syringes. J Acquir Imun Sind 1999; 20:73-80.

25. Trim JC, Elliott TJS. A review of sharps injuries and preventive strategies. J Hosp Infect 2003; 53:237-242.

26. Wicker S, Cinatl J, Berger A, Doerr HW, Gottschalk R, Rabenau HF Determination of risk of infection with blood-borne pathogens following a needlestick injury in hospital workers. Ann Occup Hyg 2008; 52:615-622.

27. Corser WD. Occupational exposure of health care workers to bloodborne pathogens: a proposal for a systemic intervention approach. Am Assoc Occup Health Nurses 1998; 46:246-252. 